\title{
Proceeding
}

Performance Analysis Workshop, 2 - 5 April 2013, Alicante, Spain

\section{Historical, tactical and structural analysis of the 4:2 defensive play system in handball}

JOSÉ J. ESPINA

Faculty of Education, University of Alicante, Spain

\begin{abstract}
Espina JJ. Historical, tactical and structural analysis of the $4: 2$ defensive play system in handball. J. Hum. Sport Exerc. Vol.8, No. Proc3, pp. S578-S590, 2013. This study aims to show how the 4-2 Defensive Play System in Handball has developed both tactically and structurally over time. Logically, since its first appearance in Czechoslovakia during the 1960s, there have been certain physical, technical and tactical changes. The System has also evolved to be used both in Grassroots Sport (from Junior to Youth) and in situations of numerical superiority. The study begins with a number of diagrams that make it easier to understand the most significant tactical aspects involved. Key words: HANDBALL, DEFENSIVE PLAY SYSTEM, DEVELOPMENT, TACTICS.
\end{abstract}

Corresponding author. Faculty of Education, University of Alicante, Campus San Vicente del Raspeig, 03080 Alicante, Spain. E-mail: jj.espina@ua.es

Performance Analysis Workshop, 2 - 5 April 2013, Alicante, Spain

JOURNAL OF HUMAN SPORT \& EXERCISE ISSN 1988-5202

(c) Faculty of Education. University of Alicante

doi:10.4100/jhse.2013.8.Proc3.03 


\section{BASIC STRUCTURE}

Any study of the 4-2 defensive System is tremendously interesting, both because of the difficulty involved in implementing it correctly and because of the variations that have appeared throughout recent history.

As its name suggests, it basically consists of placing 4 defenders in the front line and two in the second.

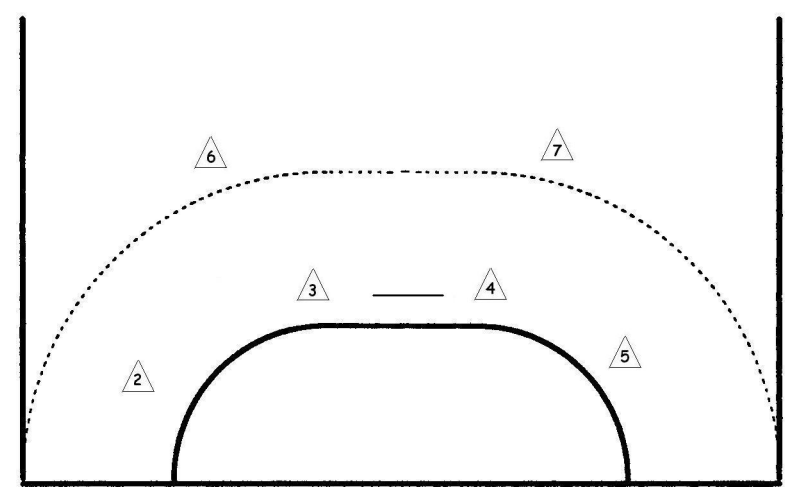

Figure 1. 4 defenders in the front line and two in the second

In principle, it is a Zone System, which provides the whole structure with symmetrical depth and makes it very solid. Notwithstanding the variables that we will analyse in the following sections, what we have is a zonal construction designed to provide the depth required by the wing and centre zones (through the two forward players), thus making it easier to mark their attacking counterparts.

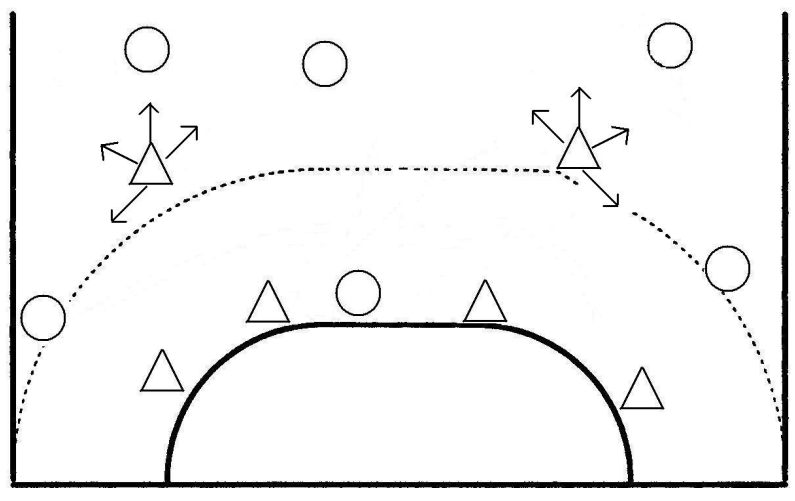

Figure 2. Two forward players

The main task of these forward players is to prevent long-distance shots from the 1st offensive line and hinder the circulation of the ball.

However, its initial focus on zone defence individualises the tasks of all the defenders, due to both the relative distance produced between them and the difficulty involved in both sliding and switching opponents. 


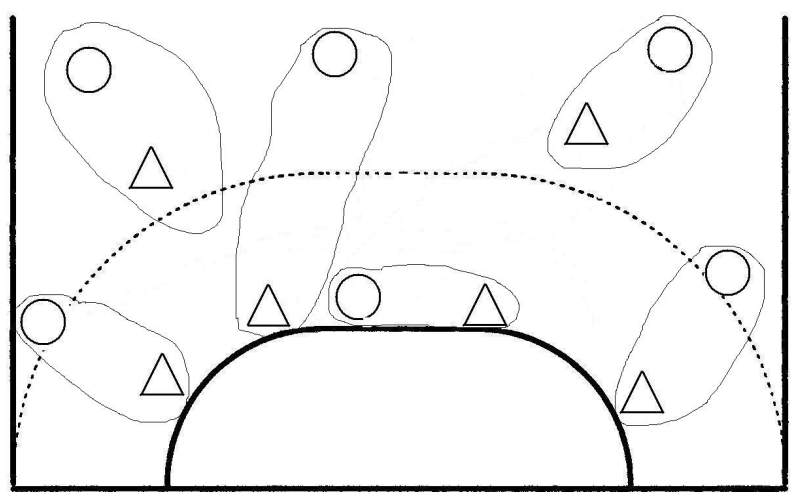

Figure 3. Prevent long-distance shots from the 1st offensive line

The basic division of responsibilities is as follows2:

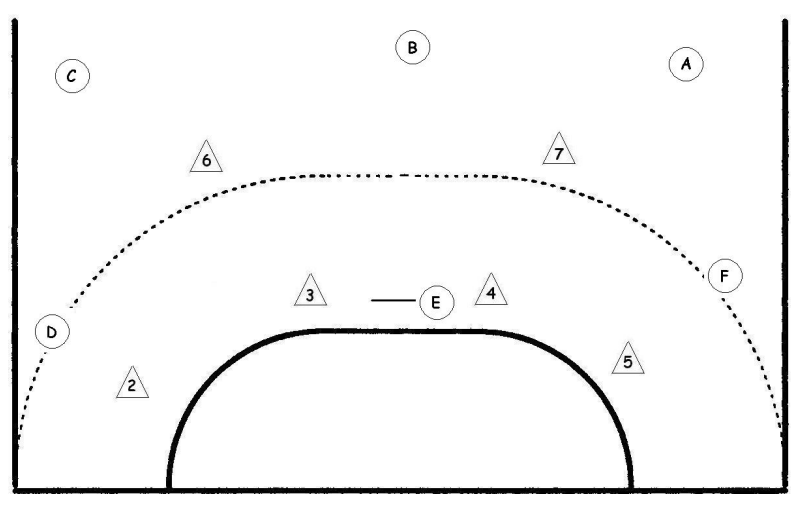

Figure 4. 2-D; 3-B; 4-E; 5-F; 6-C; 7-A

\section{Origins}

Generally speaking, the 4-2 System originated and developed with in a specific area. The defensive variant arose in the old Czechoslovakia in the early 1960s as an initial response to the "flat" 6-0 defences used at that time (Román, 1972). In this sense, it took another step (compared to the different 5-1 systems) forward as regards the concept of defence in depth and it initially reaped significant international success, leading the 4-2 System to be recognised throughout the world. Indeed, the system was first seen in 1964 during the 5th World Men's Handball Championship held in Czechoslovakia (Constantini, 2001). The host team was already a world handball power and obtained excellent results (only losing to Romania, who won the championship, in a close-fought match that ended up 16-15), winning the Bronze Medal by beating the Federal Republic of Germany by $22-15$, as well as ending the tournament as the team with least goals against. Here, we should point out that the team let in $\mathbf{8 1}$ goals in six matches, giving an average of 13.5 goals against in each match.

2 The pivot can be marked in three ways, depending on the different Czechoslovakian writers and trainers who carried out its initial development. Some considered that the central defender closest to the circulation of the ball should mark the pivot, while others felt that he should be marked by the both centres in a zone system, according to the position he takes up. Finally others believe that anticipation and change of opponents should be the basis of the marking. 


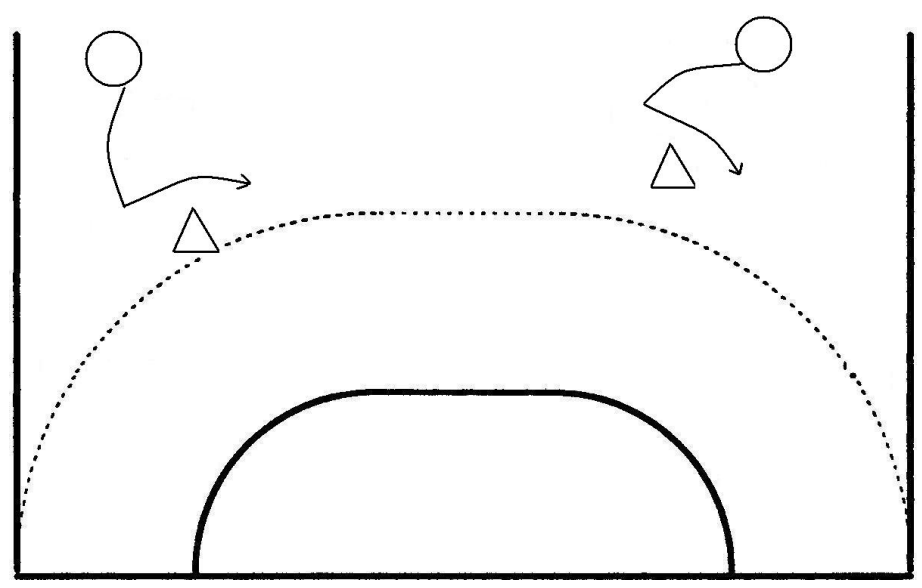

Figure 6. The search for 1-1 situations with forwards and wings B

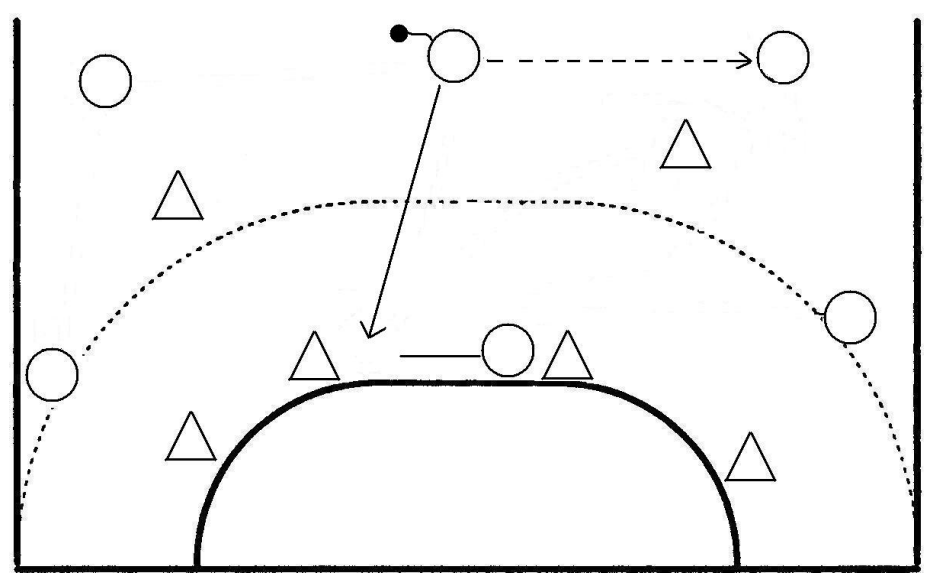

Figure 7. The switching of a player from the 1st offensive line to pivot $A$

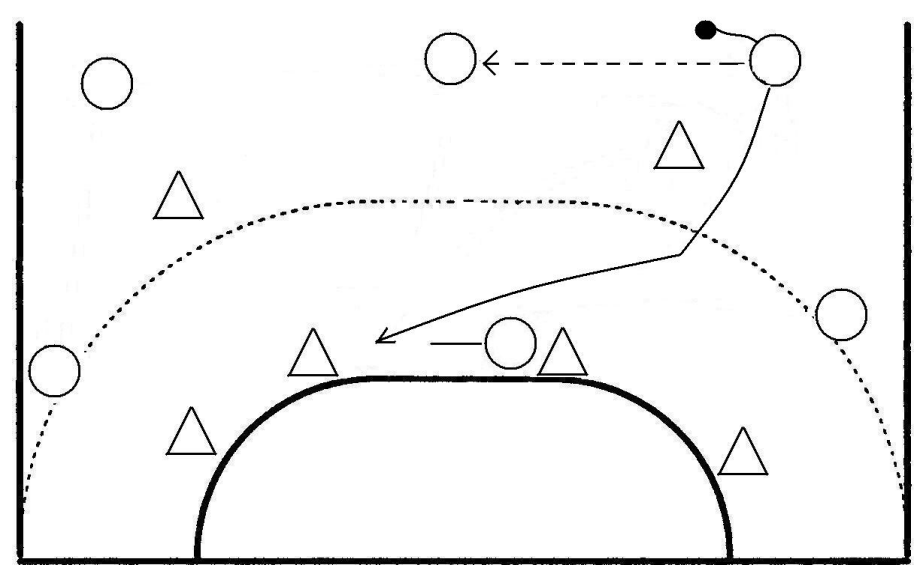

Figure 8. The switching of a player from the 1st offensive line to pivot $B$ 


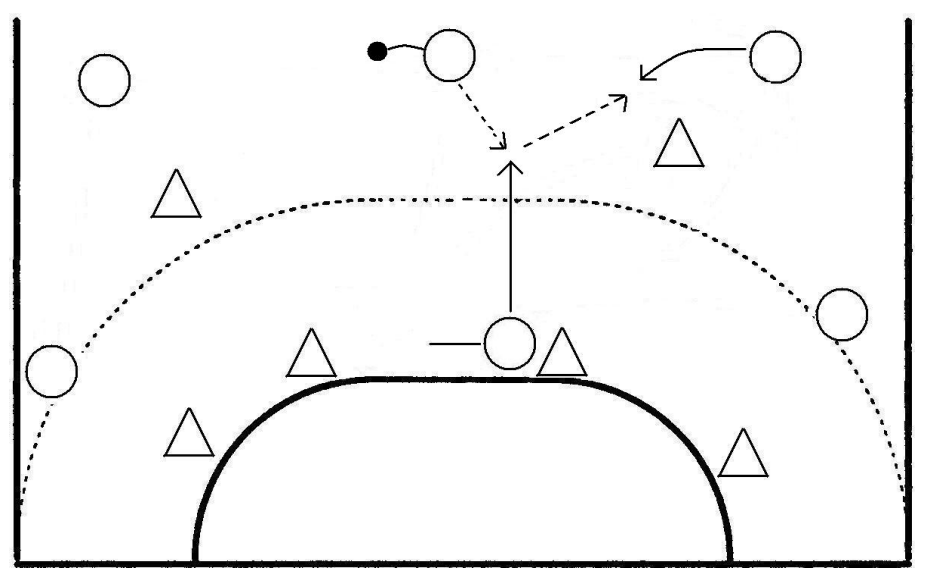

Figure 9. The pivot playing between the lines

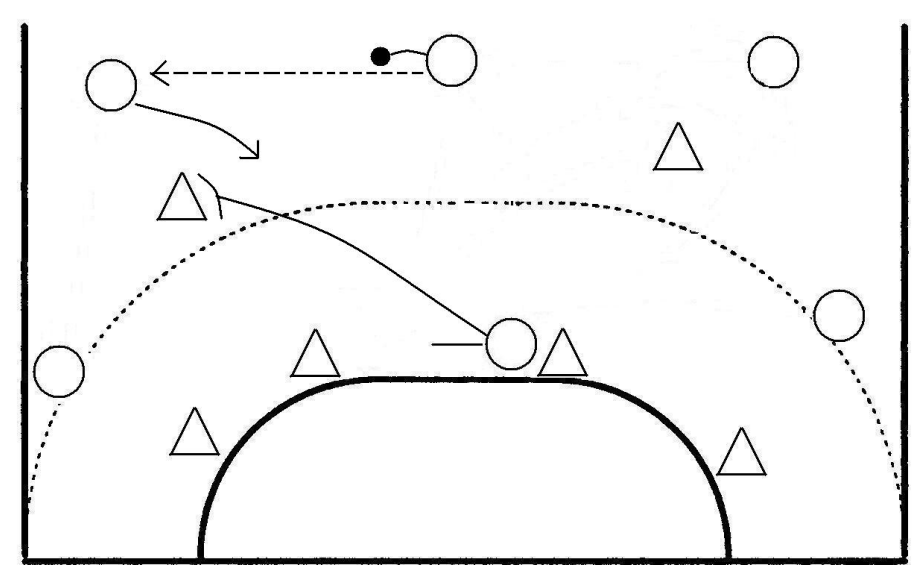

Figure 10. Pivot blocking the forward players $A$

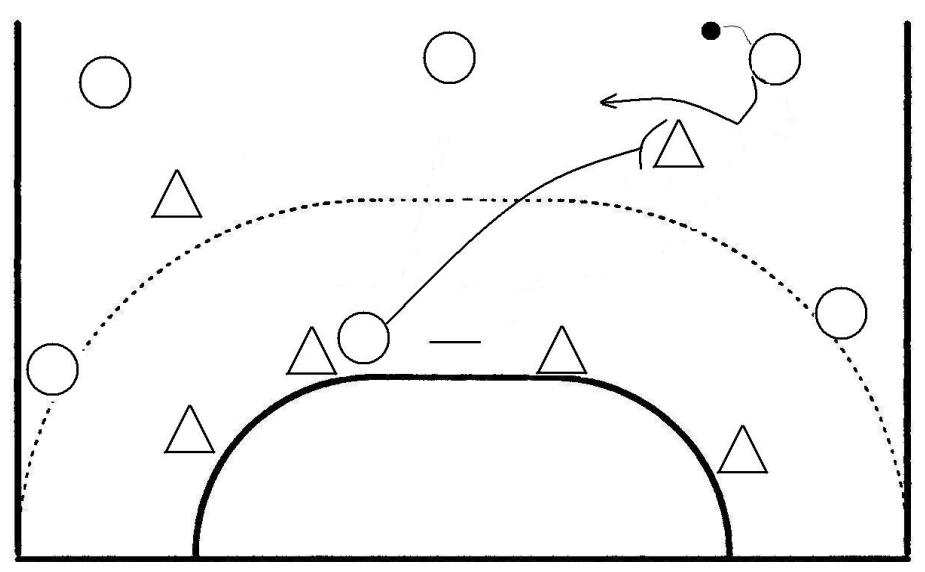

Figure 11. Pivot blocking the forward players $B$ 


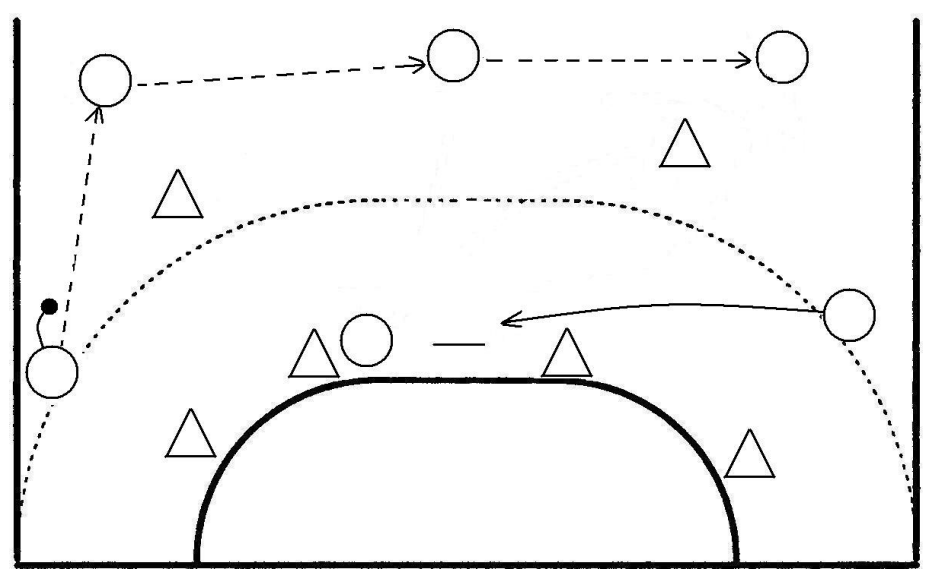

Figure 12. Circulation of the wings $A$

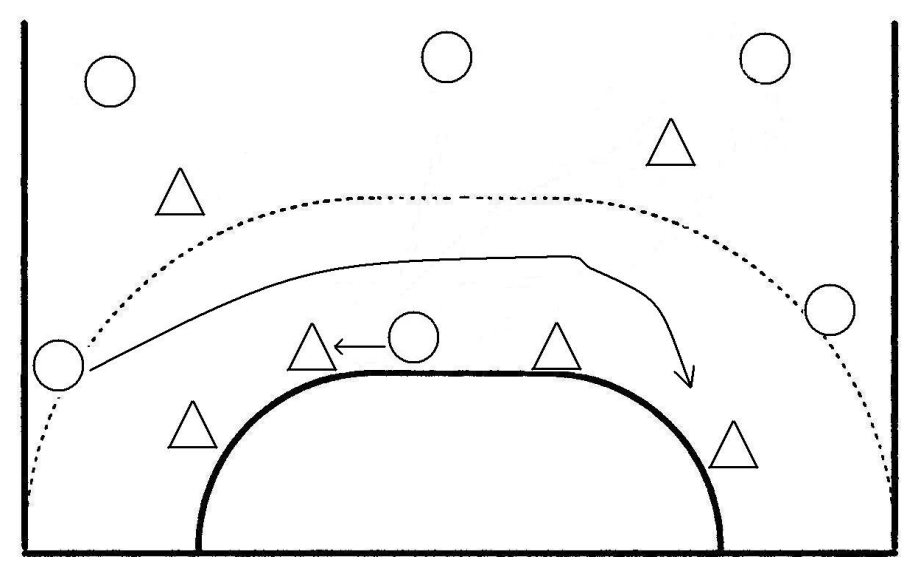

Figure 13. Circulation of the wings $B$

As well as all of the above, the early 1970s saw the cautious introduction of different variants of the zonal 42 Defensive System throughout the world. These were as follows:

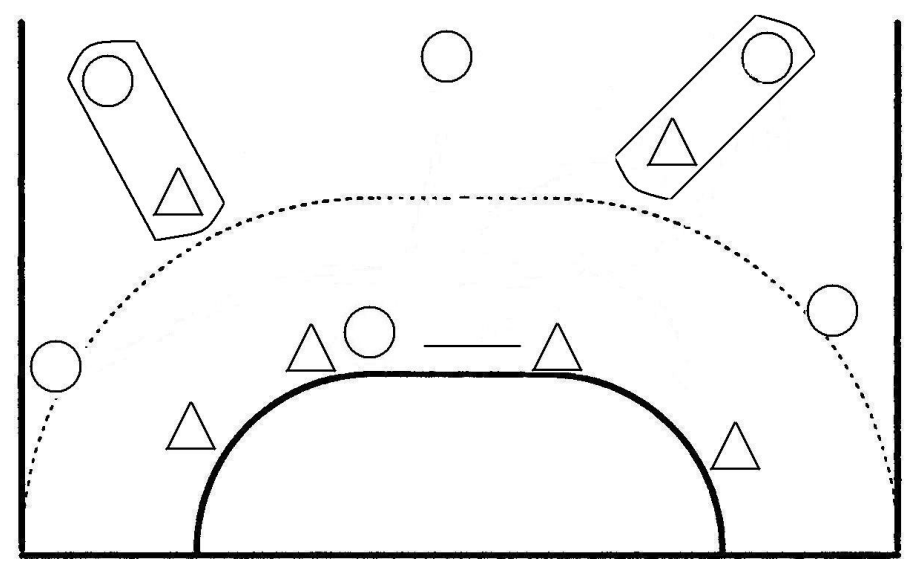

Figure14. 4-2 Defensive System - total mixed 
This clearly shows that the forward players mark Man-to-Man.

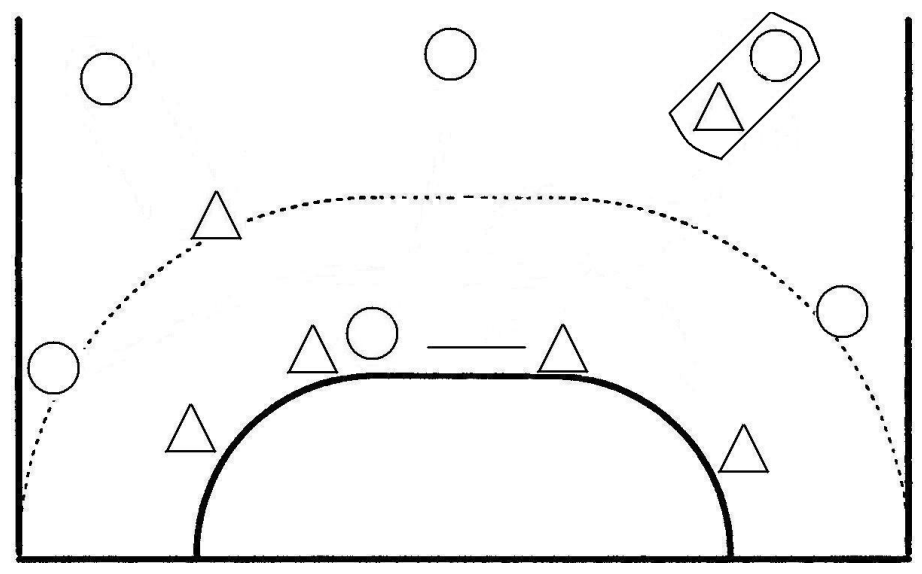

Figure 15. 4-2 Defensive System - partial mixed A

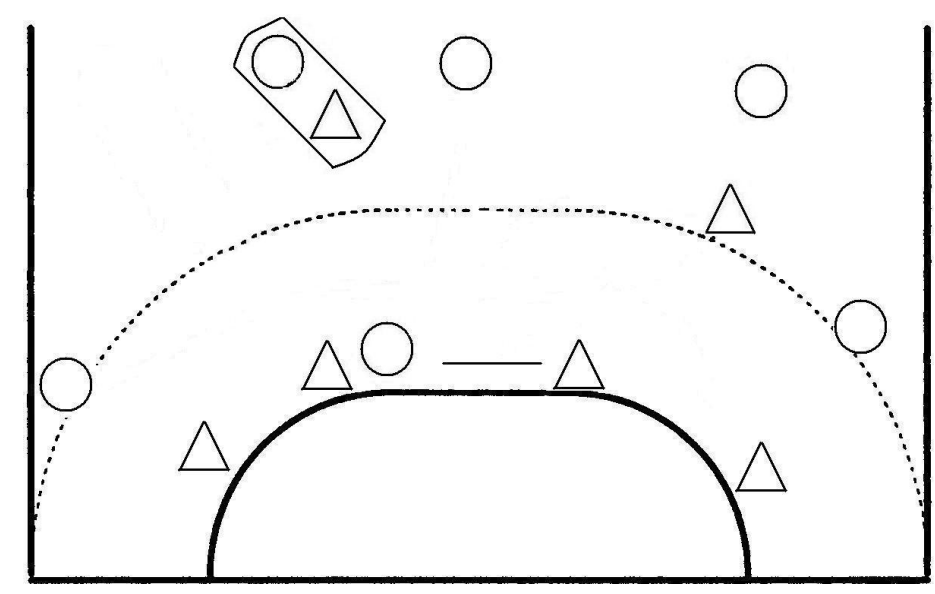

Figure 16. 4-2 Defensive System - partial mixed B

It consists of one of the players furthest forward marking his immediate opponent Man-to-Man, while the other does so by zone.

The three methods described (4-2 zonal, 4-2 total mixed and 4-2 partial mixed) have been alternated up to our days, not only in the old Czechoslovakia, but all over the world (Gutierrez, 1998; Espina, 2005), and are applied to suit the characteristics and approach of each team. However, we should admit that, in general, they are more accepted in their country of origin than elsewhere, where they are less popular, or rather only used on specific occasions in situations of numerical superiority involving 6 against 5 (Figure 17) or situations when a result is needed quickly etc. 


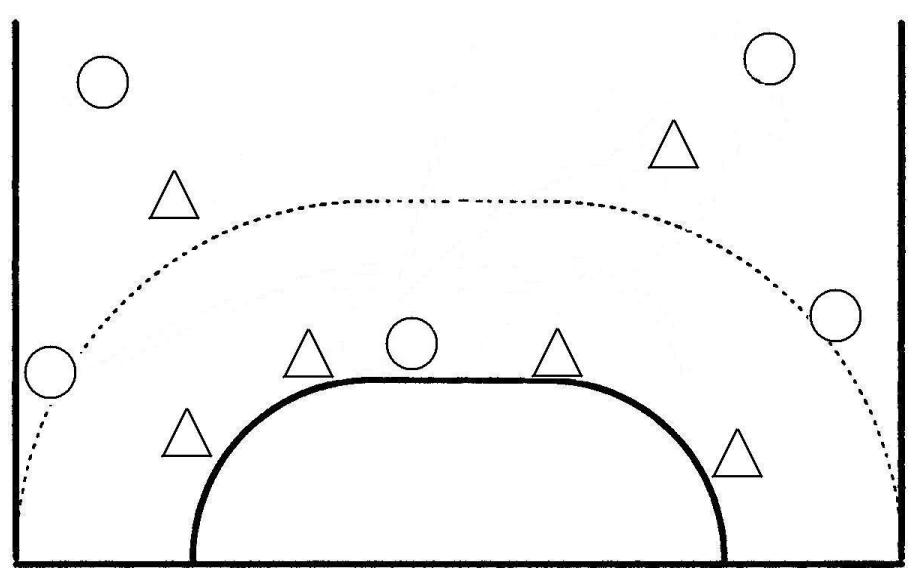

Figure 17. 6 against 5

From a geo-handball point of view, it is interesting to see how the 4-2 System developed after 1993 (Späte, 2005), when Czechoslovakia broke up into the Czech Republic and Slovakia (Espina, 1996; García, 2005). Since then, the 4-2 system has been much more widely used in the former, while it has become less popular in the latter. (Román, 2000). We would also like to underline the fact that the System is widely used by teams in Grassroots Sport (from Junior to youth), as it helps them to learn the basic concepts of individual and collective defence tactics, as well as creating (especially at these levels, where it is sometimes difficult to attack with any certainty of success) problems for the opponents (Bayer, 1983; Ávila, 2005).

\section{REFERENCES}

1. ARGILÉS C. El ataque en superioridad numérica. Zaragoza: III Clinic R.F.E.BM., 2000.

2. ÁVILA F. La formación defensiva del jugador en su incorporación al alto rendimiento. Madrid: Cuadernos Técnicos $n^{0}$ 254. Revista Área de Balonmano. A.E.BM., 2005.

3. BAYER C. Hand-Ball. La formation du joeur. París: Vigot, 1983.

4. BREGULA T. Pilka Reczna, Lata Doswiadczen. Varsovia: Biblioteca Trevesa, 1996.

5. CONSTANTINI D. Handball, un rebond vers I'avenir. París: Gagner, 2001.

6. ESPINA JJ. Balonmano. Introducción a los Sistemas de Juego. Valencia: Federación de Balonmano de la Comunidad Valenciana, 1989.

7. ESPINA JJ. La defensa en inferioridad numérica. Lanzarote: I Clinic Valero Rivera, 2005.

8. ESPINA JJ. Variaciones a los Sistemas de Juego Defensivos en el momento actual. Madrid: Cuadernos Técnicos $n^{0}$ 1. Comunicación Técnica $n^{0}$ 159. Revista Área de Balonmano. A.E.B.M, R.F.E.B.M, 1996.

9. FALKOWSKI MM, ENRÍQUEZ E. Los Sistemas de Juego Defensivos. Madrid: Esteban Sanz, 1988.

10. GARCÍA J. Interacción Defensa-Ataque. Zaragoza: VII Seminario Internacional A.E.BM, 2005.

11. GUTIERREZ O. Los Sistemas Defensivos en situaciones de desigualdad numérica. Madrid: Cuadernos Técnicos $n^{0}$ 2. Comunicación Técnica no 164. Revista Área de Balonmano. A.E.BM, R.F.E.BM, 1998.

12. KUCHENBECKER B. Sistema Defensivo 4:2. Estocolmo: Comunicación Técnica nº 16. R.F.E.BM, 1970. 
13. LAGUNA M. Una opinión sobre la evolución de las defensas. Madrid: Cuadernos Técnicos $n^{0} 245$. Revista Área de Balonmano A.E.BM, 2005.

14. MALIC Z. Rukomet. Pogled s Klupe. Zagreb: Kurtos, 1999.

15. MAYO C. Procedimientos tácticos defensivos ante cruces y bloqueos. Alcalá de Henares: II Clinic de Actualización para Entrenadores Nacionales. R.F.E.BM, 1983.

16. RIBEIRO M, VOLOSSOWITCH A. Andebol. O ensimo do andebol dos 7 aos 10 anos. Lisboa: Federação de Andebol de Portugal, 2004.

17. RIVERA V. La defensa 4:2 posicional. Buenos Aires: Curso Internacional de Balonmano. FEMEBAL, 2005.

18. ROMÁN JD. Juegos Olímpicos Munich 1972. El Balonmano. Madrid: Revista Deporte $2000 n^{\circ} 44$, 1972.

19. ROMÁN JD. La evolución del Balonmano en los últimos 25 años (1975-2000). Madrid: I Jornadas Deportivas Centro de Estudios San Pablo, 2000.

20. ROMÁN JD. Los inicios del siglo XXI. Evolución y tendencias del juego. Zaragoza: VII Seminario Internacional A.E.BM, 2005.

21. SPÄTE D. Analyse Tunisia 2005. Basilea: World Handball Magazine n 1/2005, 2005.

22. THOMAS J, NELSON J. Métodos de la investigación en la actividad física. Barcelona: Paidotribo, 2007. 


\section{APPENDIX 1}

4:2 defensive play system

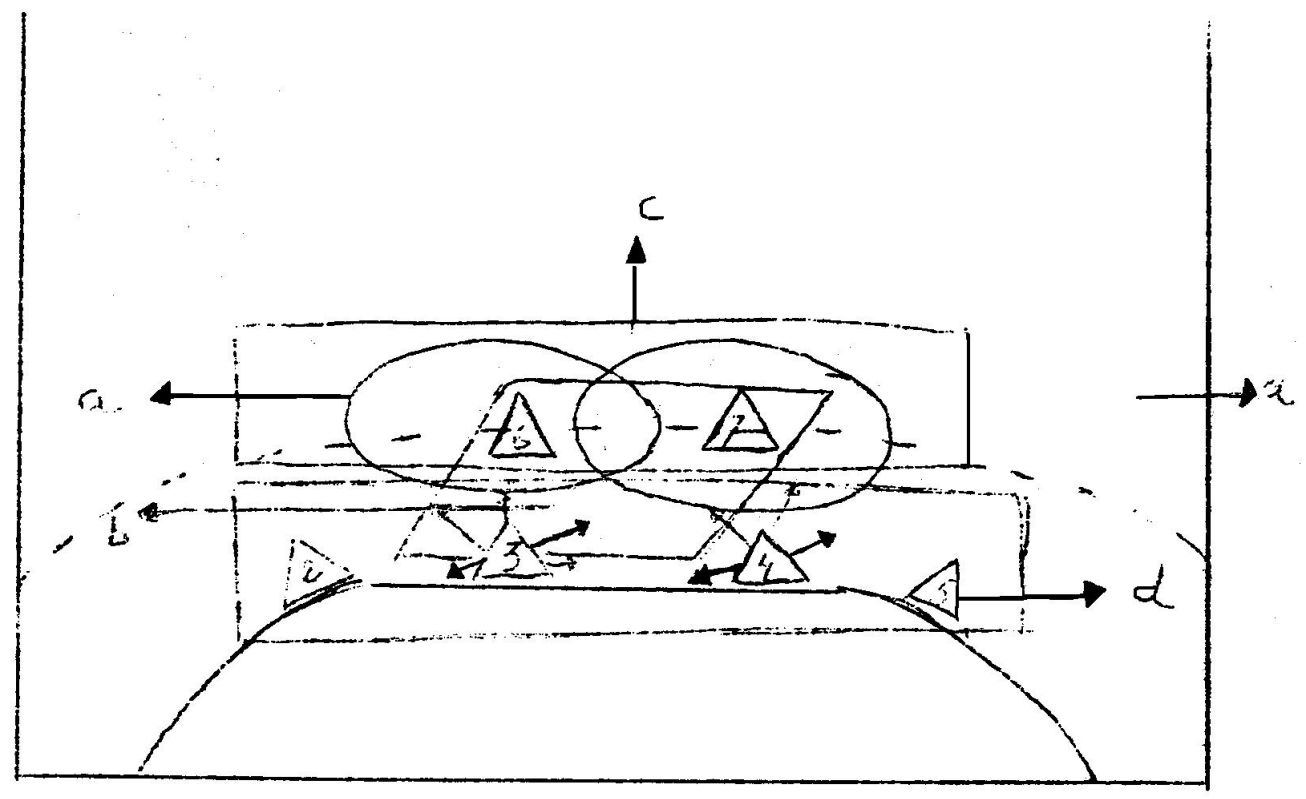

GR NO1

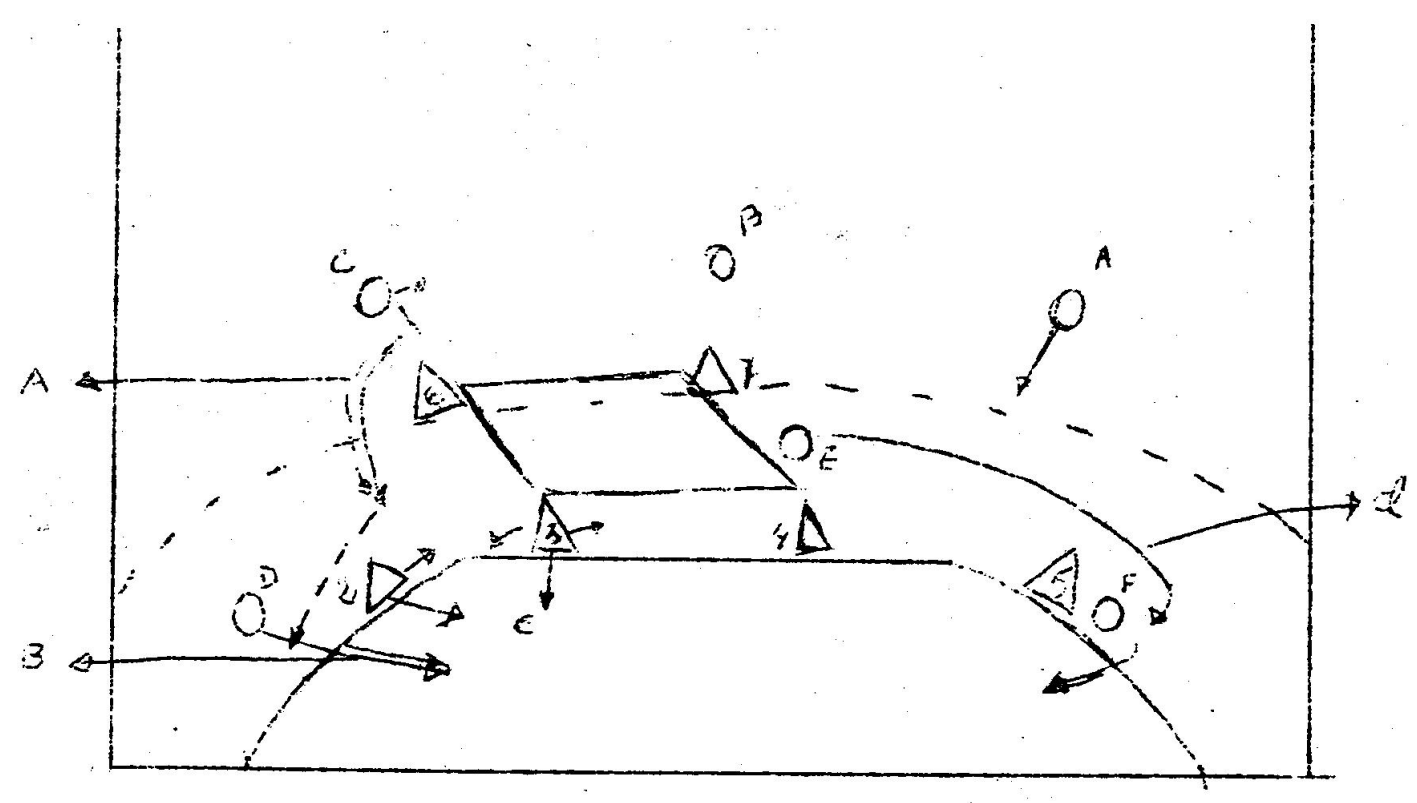

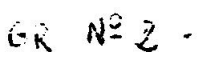



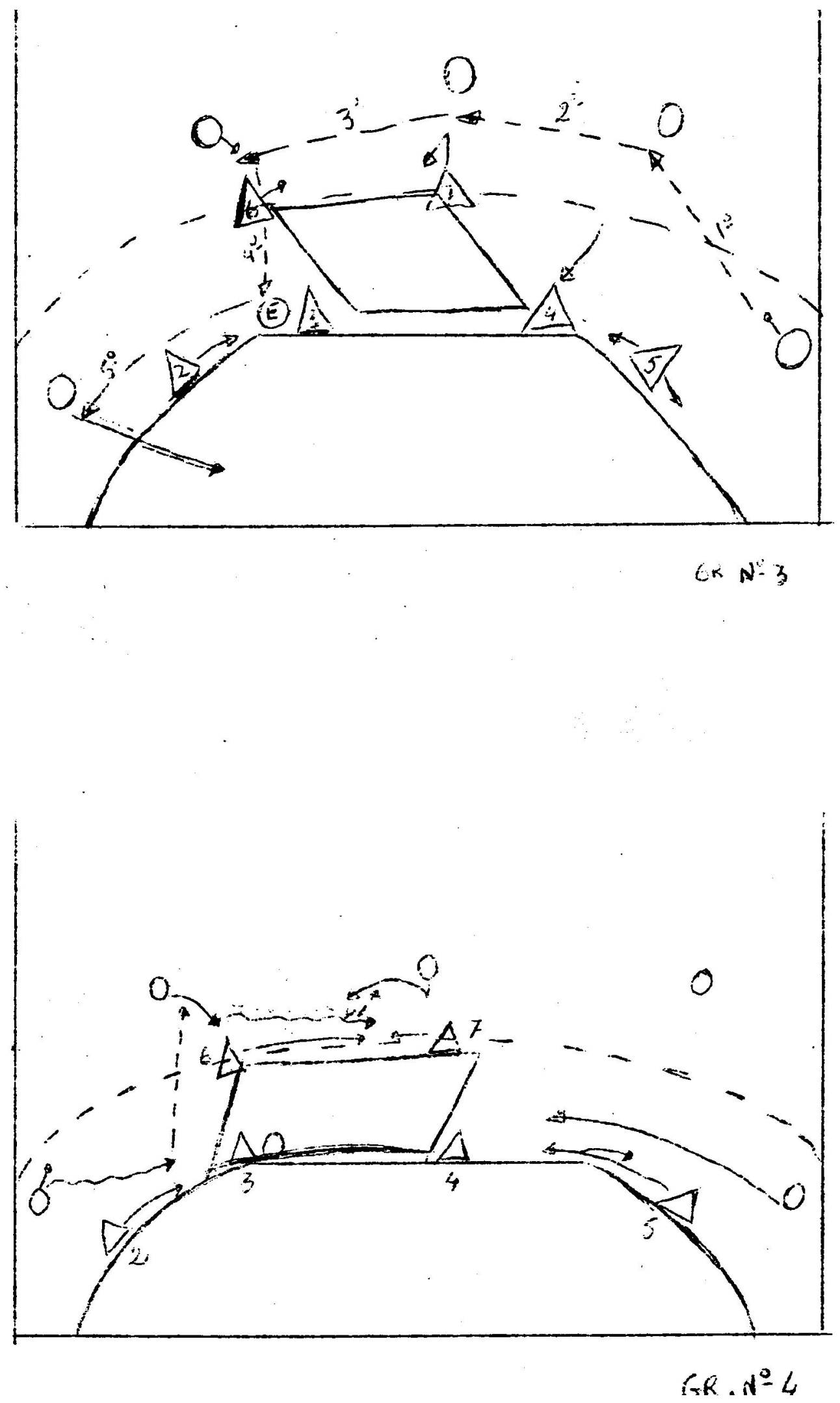


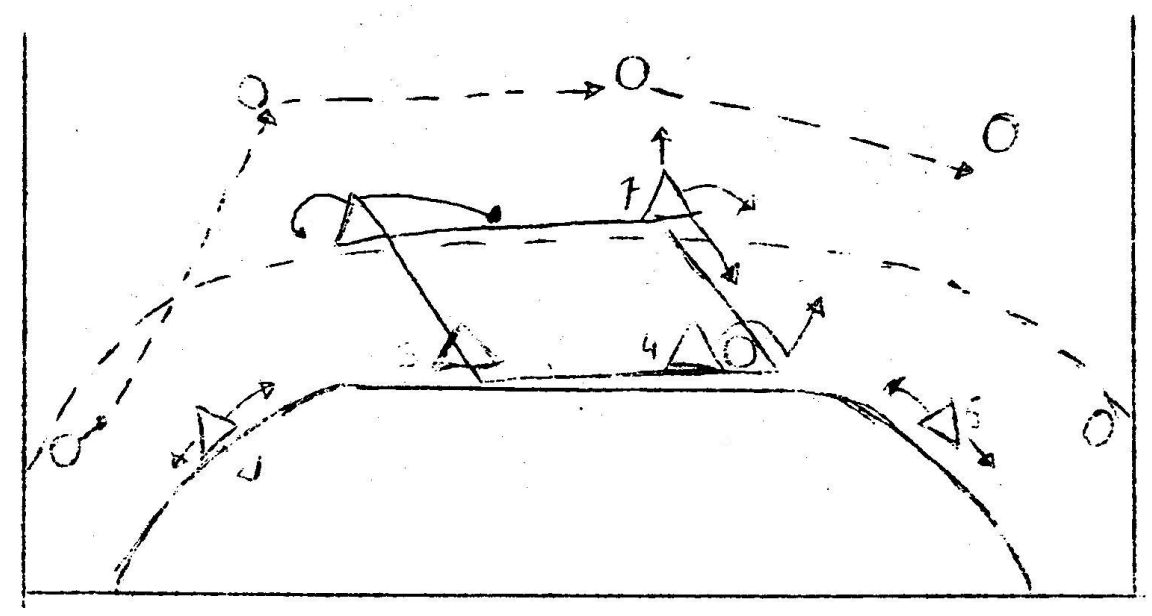

(x. $N^{3}=5$
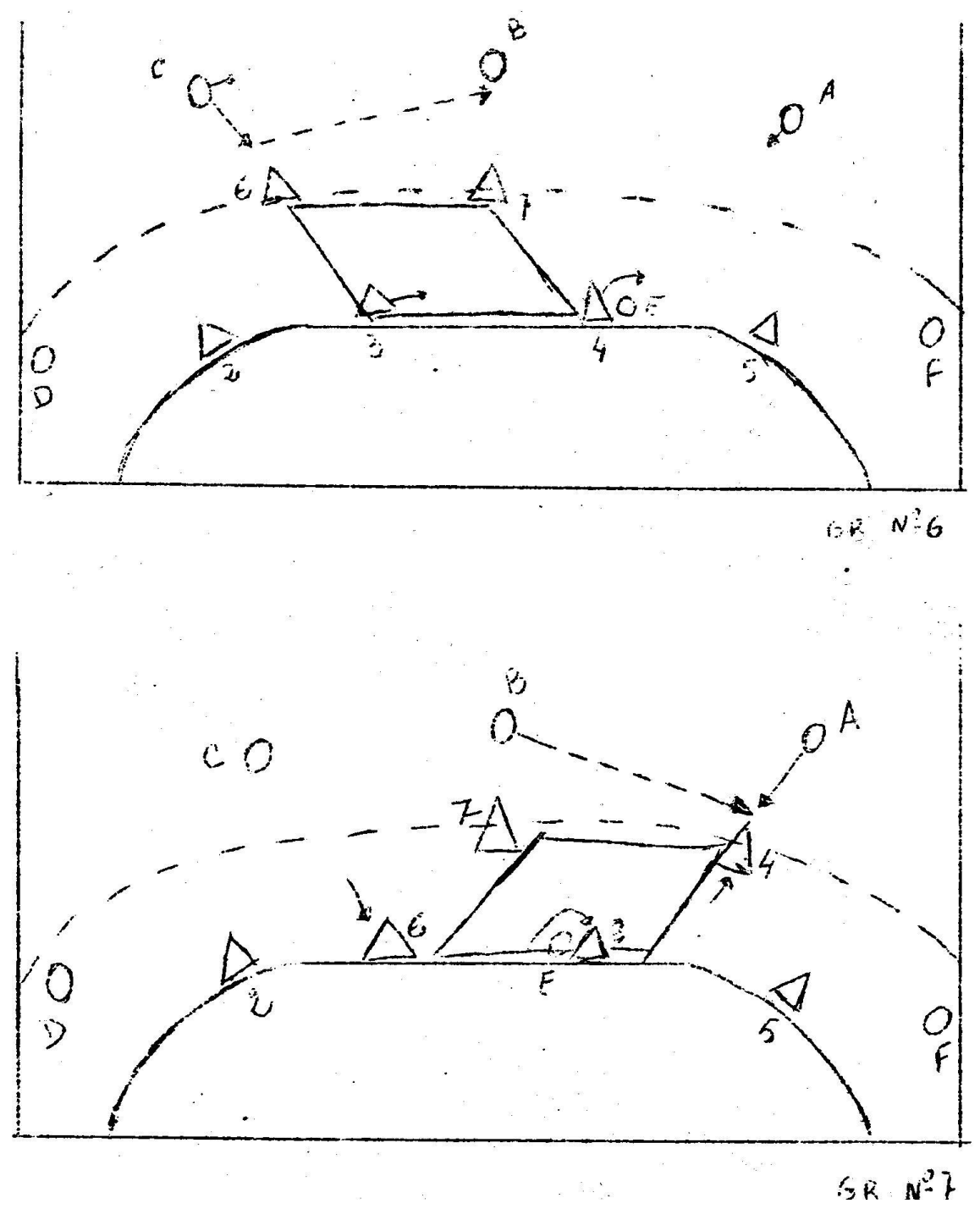